UDC 546.41.264 + 631.8

\title{
INVESTIGATION OF REACTIONS FOR PROCESSING OF SUGAR-JUICE DEFECATION SLUDGE FOR OXIDE MATERIALS AND FERTILIZERS
}

O. P. PEREPELYTSYA, SCD in Chemistry

T. V. PETRENKO, post-graduate

National University of Food Technologies

A. I. SAMCHUK, SCD in chemistry

M.P. Semenenko Institute of geochemistry, mineralogy and ore formation of the National Academy of sciences of Ukraine

At first, reactions of defecate of sugar production with acid oxides $\mathrm{MoO}_{3}, \mathrm{WO}_{3}$ (I) and phosphate acid $\mathrm{H}_{3} \mathrm{PO}_{4}$ (II) were investigated with methods of chemical analysis, pH-measuring, thermogravimeasuring and X-rays. In the system (I) separate phases with tetragonal syngony are forming, while in the system (II) the mixture of $\mathrm{Ca}_{3}\left(\mathrm{PO}_{4}\right)_{2}$, CaHPO4and $\mathrm{Ca}\left(\mathrm{H}_{2} \mathrm{PO}_{4}\right)_{2}$ are precipitating.

These products can be used as inorganic oxide materials and fertilizers or forages addings for agriculture.

Introduction. The defecate of sugar production (carbonate precipitate or sugar-juice defecation sludge) is a chemical setting of sugar-refinery, it is used as fertilizer for acid grounds $[1,2]$, its application in other industries is not known. The data published about investigations of this precipitation as adsorption for purification of waste water from textile dyestuff [3] and as component of mixtures with NPKfertilizers $[4,5]$. Studying of defecate of sugar production is not realized in other fields. That's why the purpose of this research is to study reactions of defecate of sugar production, chemical composition of which is determined for tests of two plants $[6,7]$.

The experimental part and discussion of results. For the experiment acid oxides $\mathrm{MoO}_{3}, \mathrm{WO}_{3}$, phosphate acid $\mathrm{H}_{3} \mathrm{PO}_{4}$ with qualification "A. R. purity", defecate of sugar production taken from Kapitanivskyy sugar plant of the Kirovograd region were used. Chemical composition of this sugar-juice defecation sludge (IPC-MS analysator Element 2) is represented in table 1.

Methods of chemical analysis (trilonometry [8] - for determination of quantity of $\mathrm{Ca}^{2+}$ and precipitation of $\mathrm{NH}_{4} \mathrm{MgPO}_{4}-$ for determination of quantity $\mathrm{PO}_{4}{ }^{3-}$ - ions [9]), pH-measuring ( $\mathrm{pH}$-meter Y-160 MY), termogravimeasuring (derivatograph Q-1500-D of system of P. Paulik - L. Paulik - L. Erdey, with the speed of heating $0,1667 \mathrm{grad} / \mathrm{s}$, DTA 250, DTG -500 , TG $-0,2 \cdot 10^{-3} \mathrm{~kg}$ ) and X-ray (DRON 3M with $\mathrm{Cu}_{\mathrm{k}} \alpha$-ray) are used.

Mixtures of defecate sugar production and $\mathrm{MoO}_{3}$ or $\mathrm{WO}_{3}$ were taken at ratio $\left[\mathrm{CaCO}_{3}\right]:\left[\mathrm{EO}_{3}\right]=1,0: 1,0, \mathrm{E}-\mathrm{Mo}, \mathrm{W},\left(\left[\mathrm{CaCO}_{3}\right]\right.$ - quantity of the matterin the defecate) 
1.Resultsof chemicalanalysisofcarbonate precipitate of Kapitanivskyy sugar plant

\begin{tabular}{|c|c|c|c|}
\hline $\begin{array}{c}\text { Formula of } \\
\text { oxide }\end{array}$ & $\begin{array}{c}\text { Contents ofoxide, } \\
\text { mass.\% }\end{array}$ & Element & $\begin{array}{c}\text { Contents ofelement, } \\
\text { mass.\% }\end{array}$ \\
\hline $\mathrm{SiO}_{2}$ & 5,49 & $\mathrm{Mn}$ & 0,02 \\
\hline $\mathrm{TiO}_{2}$ & 0,09 & $\mathrm{Ni}$ & 0,0002 \\
\hline $\mathrm{Al}_{2} \mathrm{O}_{3}$ & 3,13 & $\mathrm{Cd}$ & not find \\
\hline $\mathrm{Fe}_{2} \mathrm{O}_{3}$ & 0,77 & $\mathrm{Ti}$ & 0,01 \\
\hline $\mathrm{FeO}$ & 1,43 & $\mathrm{~V}$ & 0,0003 \\
\hline $\mathrm{MnO}$ & 0,01 & $\mathrm{Cr}$ & 0,0001 \\
\hline $\mathrm{MgO}$ & 1,20 & $\mathrm{Cu}$ & not find \\
\hline $\mathrm{CaO}$ & 36,56 & $\mathrm{Be}$ & not find \\
\hline $\mathrm{Na}_{2} \mathrm{O}$ & 0,14 & $\mathrm{As}$ & 0,0002 \\
\hline $\mathrm{K}_{2} \mathrm{O}$ & 0,20 & $\mathrm{~Pb}$ & 0,001 \\
\hline $\mathrm{P}_{2} \mathrm{O}_{5}$ & 0,07 & $\mathrm{Mo}$ & 0,004 \\
\hline $\mathrm{H}_{2} \mathrm{O}(\mathrm{OH}-$ group $)$ & 3,68 & $\mathrm{Zn}$ & \\
\hline ignitionloss & 46,61 & & \\
\hline sum & 99,69 & & \\
\hline
\end{tabular}

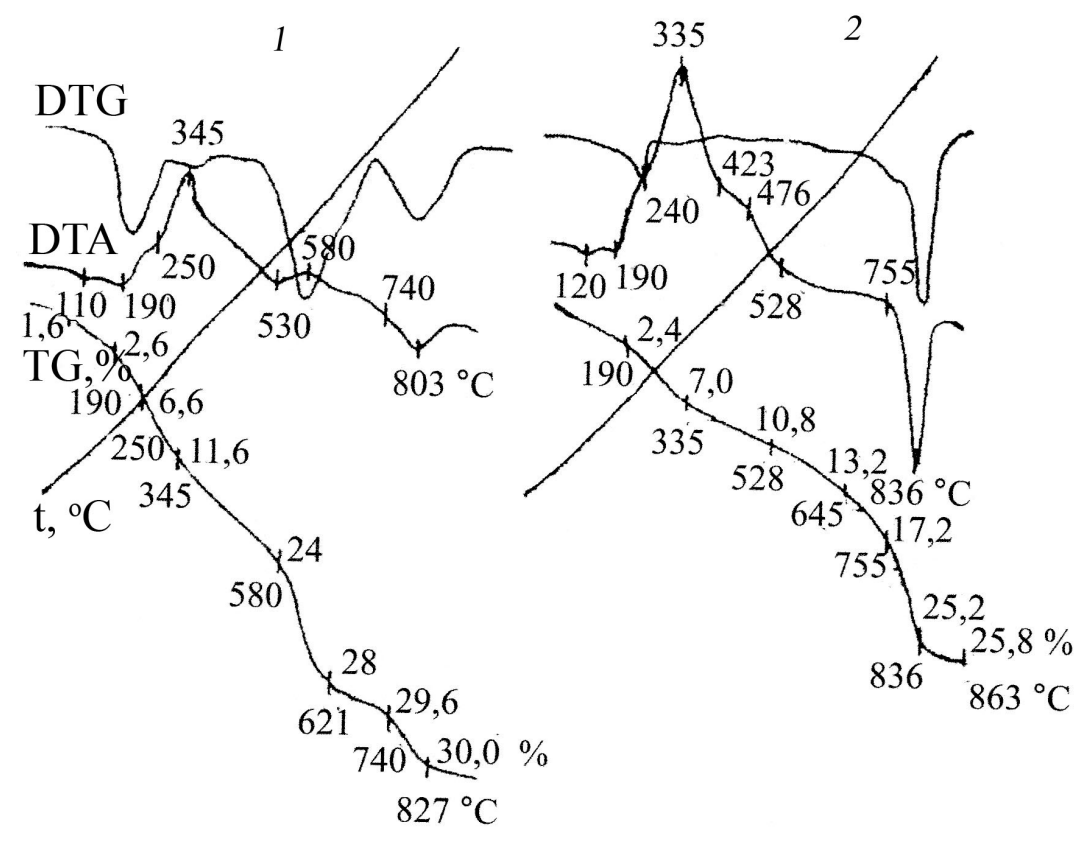

Fig. 1. Derivatogram of carbonate precipitate and oxides:

precipitate and threeoxide of molybdenum, $\left[\mathrm{CaCO}_{3}\right]:\left[\mathrm{MoO}_{3}\right]=1,0: 1,0$ (1),

precipitate and threeoxide of tungsten, $\left[\mathrm{CaCO}_{3}\right]:\left[\mathrm{WO}_{3}\right]=1,0: 1,0(2)$

Results of thermogravimetric analysis of mixtures are represented on fig. 1 and in the table 2.

Share of interaction $(\alpha)$ of carbonate pre- cipitate with acid oxides is calculated on base of loss mass (curve of TG) in dependence from temperature (fig. 2) 
2. Results of termogravimetric analysis of mixtures of calcium carbonate of defecate of sugar production and $\mathrm{MoO}_{3}$ or $\mathrm{WO}_{3}$

\begin{tabular}{|c|c|c|c|c|}
\hline $\begin{array}{c}\text { Composition of } \\
\text { mixtures }\end{array}$ & $\begin{array}{c}\text { Temperature of } \\
\text { anhydration, } \\
\mathbf{o} \mathbf{C}\end{array}$ & $\begin{array}{c}\text { Temperature of ther- } \\
\text { molysis and reduc- } \\
\text { tion of } \mathbf{E O}_{3}, \mathbf{o}_{\mathbf{C}}\end{array}$ & $\begin{array}{c}\text { Temperature } \\
\text { of interaction, } \\
\mathbf{o} \mathbf{C}\end{array}$ & $\begin{array}{c}\text { Final sub- } \\
\text { stance }\end{array}$ \\
\hline $\begin{array}{c}{\left[\mathrm{CaCO}_{3}\right]:\left[\mathrm{MoO}_{3}\right]=} \\
1,0: 1,0\end{array}$ & $110-190$ & $250-530$ & $580-827$ & $\mathrm{CaMoO}_{4}$ \\
\hline$\left[\begin{array}{c}{\left[\mathrm{CaCO}_{3}\right]:\left[\mathrm{WO}_{3}\right]=} \\
1,0: 1,0\end{array}\right.$ & $120-190$ & $240-528$ & $645-863$ & $\mathrm{CaWO}_{4}$ \\
\hline
\end{tabular}

Nature of finished products of these reactions was studied by X-ray and defined that its belong to tetragonal symmetry with parameters for $\mathrm{CaMoO}_{4} \mathrm{a}=0,5237 \pm 0,0002$ $\mathrm{nm} ; \mathrm{c}=1,147 \pm 0,0005 \mathrm{~nm}$; for $\mathrm{CaWO}_{4} \mathrm{a}=$ $0,5225 \pm 0,0002 \mathrm{~nm} ; \mathrm{c}=1,144 \pm 0,0005 \mathrm{~nm}$. The difference of these values of parameters of elementary cells from literature facts [10] is caused by admixtures of $\mathrm{MnO}, \mathrm{Fe}_{2} \mathrm{O}_{3}$, $\mathrm{SiO}_{2}, \mathrm{TiO}_{2}$ and $\mathrm{ZrO}_{2}$ in prepared products, thus they are modified oxide materials for metallurgy [11].

$\mathrm{CaCO}_{3}$ of defecate belong to hexagonal symmetry with parameter $\mathrm{a}=0,498 \pm 0,002$ $\mathrm{nm}, \mathrm{c}=0,853 \pm 0,005 \mathrm{~nm}$.

The results of application of those methods confirm the following process or reactions:

$\mathrm{EO}_{3}+\mathrm{C}_{\mathrm{x}} \mathrm{H}_{\mathrm{y}} \mathrm{O}_{\mathrm{z}}$ (organic phase) $\rightarrow \mathrm{EO}_{3-\mathrm{x}}$ $+\mathrm{CO}_{2} \uparrow+\mathrm{y} / 2 \mathrm{H}_{2} \mathrm{O} \uparrow$;

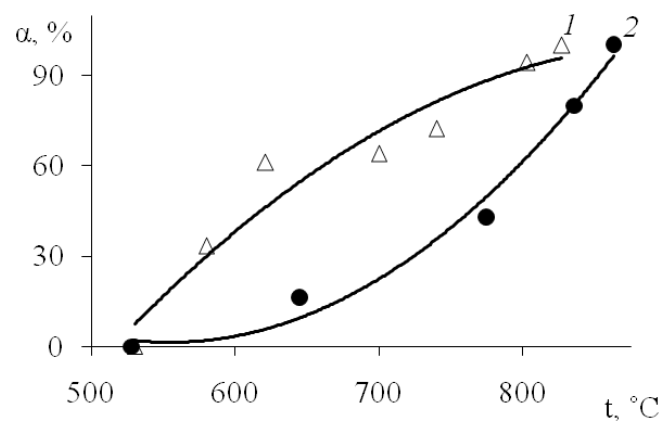

Fig. 2. Dependence of share interaction $(\alpha)$ of carbonate precipitate with acid oxides from temperature $(\mathrm{t})$ :

$\left[\mathrm{CaCO}_{3}\right]:\left[\mathrm{MoO}_{3}\right]=1,0: 1,0$ (1);

$\left[\mathrm{CaCO}_{3}\right]:\left[\mathrm{WO}_{3}\right]=1,0: 1,0(2)$
$2 \mathrm{EO}_{3}+\mathrm{xO}_{2} \rightarrow 2 \mathrm{EO}_{3}$

$\mathrm{CaCO}_{3}+\mathrm{EO}_{3} \rightarrow \mathrm{CaEO}_{4}+\mathrm{CO}_{2} \uparrow, \mathrm{E}-\mathrm{Mo}, \mathrm{W}$.

Chemical interaction $\mathrm{H}_{3} \mathrm{PO}_{4}$ with sugar-juice defecation sludge was studied too. For this purpose variable quantities of volumes $2,11 \cdot 10^{3} \mathrm{~mol} / \mathrm{m}^{3} \mathrm{H}_{3} \mathrm{PO}_{4}$ were added to constant mass of carbonate precipitation $\left(1 \cdot 10^{-3} \mathrm{~kg}\right)$ and water to $5 \cdot 10^{-5} \mathrm{M}^{3}$. The specified ratios $\left[\mathrm{PO}_{4}{ }^{3-}\right]:\left[\mathrm{Ca}^{2+}\right]$ in the heterogeneous system were changed from 1,00:0,17 to1,0:3,0. Mixtures after one month of retention and mixing were filtrated. Then $\mathrm{pH}$ and concentrations of $\mathrm{Ca}^{2+}$ and $\mathrm{PO}_{4}{ }^{3-}$ were determined. The precipitations underwent the X-ray and the thermo-gravimetric analysis. The fig. 3 below shows thepH dependence of filtrate from the specified ratios $\left[\mathrm{PO}_{4}{ }^{3-}\right]:\left[\mathrm{Ca}^{2+}\right]$. Reaction of sugar-juice defecation sludge and $\mathrm{H}_{3} \mathrm{PO}_{4}$ is accompanied with the change of $\mathrm{pH}$ quantities from 8,1 to

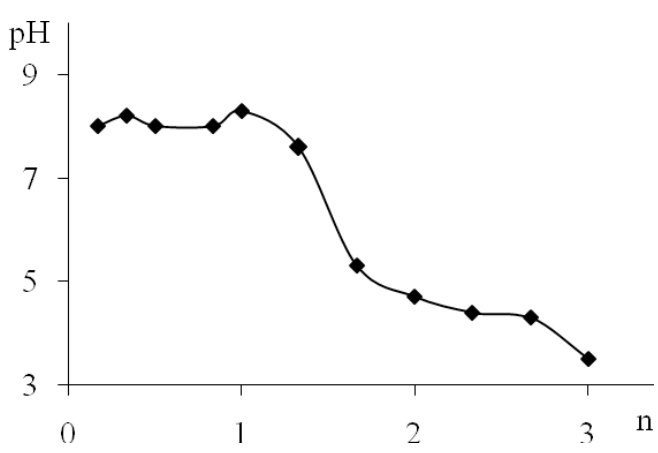

Fig. 3. pH dependence in the system filtrate: carbonate precipitate $-\mathrm{H}_{3} \mathrm{PO}_{4}-\mathrm{H}_{2} \mathrm{O}$ from the specified ratios $\left[\mathrm{PO}_{4}{ }^{3-}\right]:\left[\mathrm{Ca}^{2+}\right],(\mathrm{n})$. 


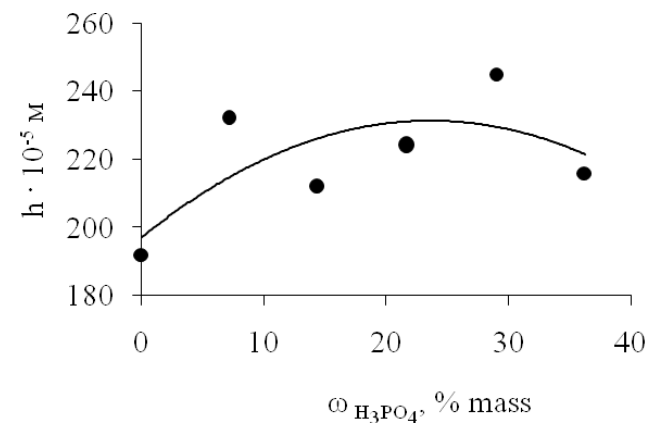

Fig. 4.Dependence of height $( \pm 0,002 \mathrm{~m})$ of vegetables rye from contain $\mathrm{H}_{3} \mathrm{PO}_{4}$ into mixture with carbonate precipitate (19 days of growth, subsandy ground)

4,4 and corresponds to the specified ratios $\left[\mathrm{PO}_{4}{ }^{3-}\right]:\left[\mathrm{Ca}^{2+}\right]$ from $1,0: 1,0$ to $1,00: 2,33$.

$\mathrm{X}$-ray of precipitations is determinate the forming mixtures ofCa $3\left(\mathrm{PO}_{4}\right)_{2}$, $\mathrm{CaHPO}_{4}$ and $\mathrm{Ca}\left(\mathrm{H}_{2} \mathrm{PO}_{4}\right)_{2}$ at the specified ratios $\left[\mathrm{PO}_{4}{ }^{3-}\right]:\left[\mathrm{Ca}^{2+}\right]=1,5: 1,0 ; 1,0: 1,0$ and
$1,0: 2,0$. It is possible in case if the next reactions or processes take place:

$$
3 \mathrm{CaCO}_{3}+2 \mathrm{H}_{3} \mathrm{PO}_{4}=\mathrm{Ca}_{3}\left(\mathrm{PO}_{4}\right)_{2}+
$$
$3 \mathrm{CO}_{2} \uparrow+3 \mathrm{H}_{2} \mathrm{O} \uparrow$;

$$
\mathrm{CaCO}_{3}+\mathrm{H}_{3} \mathrm{PO}_{4}=\mathrm{CaHPO}_{4}+3 \mathrm{CO}_{2} \uparrow+
$$

$3 \mathrm{H}_{2} \mathrm{O} \uparrow$;

$\mathrm{CaCO}_{3}+2 \mathrm{H}_{3} \mathrm{PO}_{4}=\mathrm{Ca}\left(\mathrm{H}_{2} \mathrm{PO}_{4}\right)_{2}+$ $\mathrm{CO}_{2} \uparrow+\mathrm{H}_{2} \mathrm{O} \uparrow$;

$\mathrm{Ca}$ (polygalactur. $)_{\mathrm{x}}+2 \mathrm{H}_{3} \mathrm{PO}_{4} \rightarrow$ $2 \mathrm{xH}$ (polygalactur. $)+\mathrm{Ca}\left(\mathrm{H}_{2} \mathrm{PO}_{4}\right)_{2}$.

Polygalactur is aremainofpolygalaturonacid.

Phosphate fertilizers were prepared on base of those investigations and tested on growth of wheaten or rye seeds, positive biological effect was obtained (fig. 4)[12].

Fulfiled experimental work is having letiny possibility to form scheme of researches and processing of sugar-juice defecation sludge (fig. 5), it is having practical meaning for industry as of Ukraine as of foreing countries.

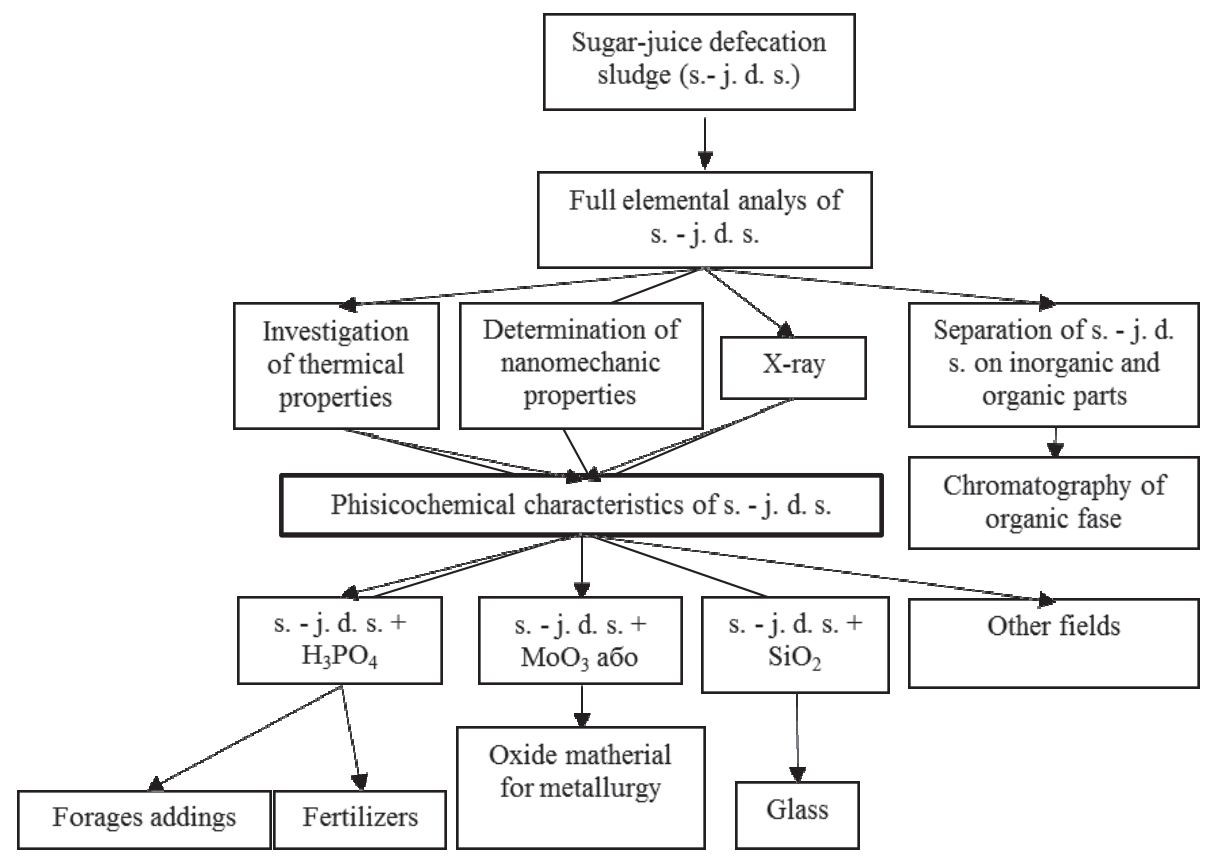

Fig. 5. Scheme of investigation and processing of sugar-juice defecation sludge for different fields 


\section{Conclutions}

Reactions of sugar-juice defecation sludge with $\mathrm{MoO}_{3}, \mathrm{WO}_{3}$ or $\mathrm{H}_{3} \mathrm{PO}_{4}$ were investigated. The determined products of those reactions are could be useful for technology processing of industrial carbonate precipitation to oxide materials or to phosphate fertilizers and forages addings for agriculture.

\section{Картотека ASTM, США}

Перепелиця О., Самчук А., Фоменко В.:Пат. Україна 85942, Опубл. 10.03.2009.

Перепелиця О., Самчук А., Іщенко В., Петренко Т., Попенко Е., Огар Т.: Пат. Україна 105146, Опубл. 10.04.14.

\section{References}

1. Pysarenko S .(2010).Proceedings of the Kharkov National University of Agriculture,99, 256.

2. Myazyn N.(1997).Agrochemistry, 2, 26.

3. Sverhuzova Zh.,Elnykov D.(2010).Scientific and technical collection "municipal services of city",93, 201.

4. Trofymov Y., Stupyna L.(2006).The News of Altai State Agrarian University,2 (22), 20.

5. Sypko A., Honcharuk H.(2014).Sugar beet, 1, 12.

6. Perepelytsa A., Yshchenko V., Samchuk A.(2014), Sugar,2, 41.

7. Perepelytsya O., Samchuk A., Pyshchay I., Petrenko T., Ishchenko V.(2014). Ukrainian chemical journal,81(4), 88.

8. Samchuk A., Pylypenko A.(1987). Analytical Chemistry of Minerals. VNU. SCIENCE, Netherlands.

9. Lyamekova Ya.(1974). Analytical chemistry of phosphorus. Moscow: Nauka (in Russia).

10. Card Index of ASTM, USA

11.PerepelytsyaO.,SamchukA.,FomenkoV.(2009).Patent of Ukraine № 85942; publisted 10.03.2009.

12.PerepelytsyaO.,SamchukA.,IshchenkoV.,PetrenkoT.,PopenkoE.,OharT.(2014).Patent ofUkraine №105146;publisted10.04.2014.

\section{АНОТАЦІЯ}

О. П. Перепелиия, Т. В. Петренко, A. I. Самчук. Дослідження реакиій для переробки дефекату иукрового виробничтва на оксидні матеріали $і$ добрива // Біоресурси $i$ природокористування. - 2016. - 8, №5-6. C.18-23.

Вперше методами хімічного аналізу, рН-метрї, термогравіметрї $і$ рентгенографічно досліджено реакиїдефекату иукрового виробниитва з кислотними оксидами $\mathrm{MoO}_{3}, \mathrm{WO}_{3}$ (I) та фосфатною кислотою ${ }_{3} \mathrm{PO}_{4}(\mathrm{II}) . \quad \mathrm{B}$ системі (I) утворюютвся індивідуальні фази з тетрагональною сингонією, тоді як у системі (II) осаджується суміш $\mathrm{Ca}_{3}\left(\mathrm{PO}_{4}\right)_{2}, \mathrm{CaHPO}_{4} i$ $\mathrm{Ca}\left(\mathrm{H}_{2} \mathrm{PO}_{4}\right)_{2}$.

Ці продукти можуть бути використані як оксидні неорганічні матеріали $і$ добрива або кормові добавки для сільсъкого господарства.

\section{АННОТАЦИЯ}

А. П. Перепелица, Т. В. Петренко, А. И. Самчук. Исследование реакиий для переработки дефеката сахарного производства на оксидные материаль и удобрения / /Биоресурсъь и природопользование. - 2016. - 8, №5-6. C.18-23.

Впервые методами химического анализа, рН-метрии, термогравиметрии и рентгенографически исследовань реакиии дефеката сахарного производства с кислотными оксидами $\mathrm{MoO}_{3}, \mathrm{WO}_{3}$ (I) и фосфатной кислоть $\mathrm{H}_{3} \mathrm{PO}_{4}(\mathrm{II})$. В системе (I) образуются индивидуальные фазы с тетрагональной сингонией, тогда как в системе (II) осаждается смесь $\mathrm{Ca}_{3}\left(\mathrm{PO}_{4}\right)_{2}, \mathrm{CaHPO}_{4} u \mathrm{Ca}\left(\mathrm{H}_{2} \mathrm{PO}_{4}\right)_{2}$.

Эти продукты могут бать использованъ как оксидне неорганические материалы и удобрения или кормовъе добавки для сельского хозяйства. 